\title{
ENDIANDRA KASSAMENSIS (LAURACEAE), A NEW SPECIES FROM NEW GUINEA
}

\author{
DEBI ARIFIANI ${ }^{1 *}$, ADI BASUKRIADI ${ }^{2} \&$ TATIK CHIKMAWATI $^{3}$ \\ ${ }^{1}$ Herbarium Bogoriense, Botani Division, Research Center for Biology-LIPI \\ Jl. Raya Jakarta Bogor Km. 46, Cibinong 16911, Indonesia \\ ${ }^{2}$ Biology Department, Faculty of Mathematics and Natiural Science, Univesitas Indonesia \\ UI Campus, Depok 16424, Indonesia \\ ${ }^{3}$ Biology Department, Faculty of Mathematics and Natiural Science, Bogor Agricultural University \\ Bogor 16680, Indonesia
}

Received 19 July 2012/Accepted 29 November 2012

\begin{abstract}
A new species of Endiandra (Lauraceae) is described from New Guinea. Endiandra kassamensis is described based on specimens collected over four decades ago. Unlike most Endiandra which grow in lowland forest, E. kassamensis is found in high altitude forest. The species is characterized by the presence of staminodia with the absence of staminal glands..
\end{abstract}

Key words: Endiandra, Lauraceae, staminal glands, staminodia, endemic, New Guinea

\section{INTRODUCTION}

Endiandra is a medium-sized genus within the avocado family (Lauraceae) and consists of over 100 tree species. Endiandra is generally known for its tree habit characterized by simple, spirally arranged and pinnately-veined leaves. According to van der Werff and Richter (1996), Endiandra is grouped together with Beilschmiedia, Cryptocarya and Potameia in the tribe Cryptocaryeae based on the type of their inflorescences which is paniculate type II in which the flowers of the ultimate cyme are not strictly oppposite. The flowers are bisexual with 3 stamens (rarely 2 or 6 ) having 2celled anthers; the ovary is superior, producing fruits in the form of drupe which are free on the receptacles.

Endiandra glauca is the type species of the genus and was described from Australia (Brown 1810). Australia houses 38 species of Endiandra (Hyland 1989) and rest of the species are distributed mostly in Malesian regions with very few in East Asia and Pacific Islands and extending north to southern China. New Guinea is the largest island in Malesian regions and a recent study on the species of Endiandra revealed that

\footnotetext{
*Corresponding author : debyarifiani@yahoo.com
} 
there are 46 species in that island with a high number of endemic species (Arifiani 2012, unpubl.). The species of Endiandra occurred generally in lowland forests (from 0 - $600 \mathrm{~m}$ above sea level) and the number of species decreases at higher altitude in montane forest (above $1000 \mathrm{~m}$ ).

Delimiting species of Endiandra requires both vegetative and floral characters evaluation. The characters evaluated include indument in all part surfaces, leaf, inflorescence, tepal, stamen, staminal glands, staminodia and fruit. Detailed observation of the characters in several specimens suggested that the specimens of Coode and Dockrill 32655 and Womersley and Vandenberg 37195 represent an undescribed species.

\section{MATERIALS AND METHODS}

The description of Endiandra kassamensis was done using herbarium specimens available at Herbarium Bogoriense (BO) and loan specimens from Singapore Botanic Gardens (SING). The study was carried out following methods of Rifai (2011) in species enumeration. Specimen characterization was done to collect morphological data by observing the characters of all specimens under the microscope (Table 1). All measurements, the number and states of the characters were noted including their position, color, fragrance, texture, density and shapes. All measurements are for dried specimens or as otherwise stated. Characterization method and botanical terms used

Table 1. Characters observed in the taxonomic study (Kostermans 1957, Rohwer 1993)

\begin{tabular}{ll}
\hline Plant parts & Characters \\
\hline Habit & height; width \\
Twig & color; indument type, orientation and density \\
Terminal bud & indument; shape; size \\
Leaf & arrangement; texture \\
Leaf blade & shape; size; apex; base; surface \\
Midrib & texture \\
Lateral veins & number; angle \\
Minor venation & reticulation density \\
Petiole & shape; indument; length \\
Inflorescence & type; position; length; indument \\
Pedicel & indument; length \\
Bract & shape; size \\
Receptacle & depth; indument \\
Tepal & opening; shape; size; indument \\
Stamens & number; shape; indument; size \\
Glands & number; shape; indument; size \\
Staminodes & number; shape; indument; size \\
Pistil & shape; indument; length \\
Fruit & shape; size \\
\hline
\end{tabular}


followed Veldkamp (1987). Characters observed were compared and correlated to each other in order to assign specimens to a discrete taxon. Finally, description for each species was created, including information on distribution, habitat and ecology, and notes on the specific characters important for the taxon.

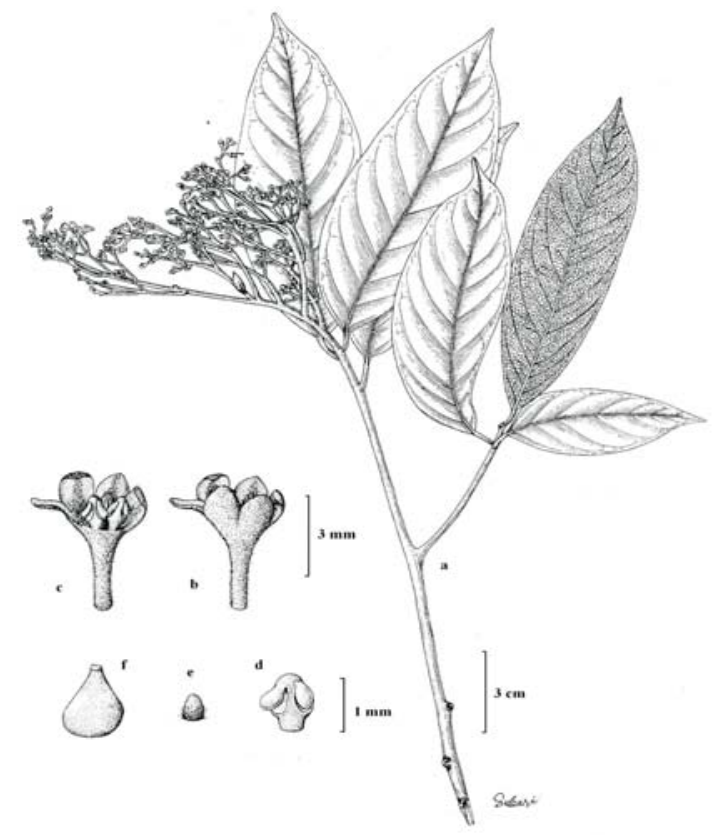

Figure 1. Endiandra kassamensis Arifiani. a. habit; b. intact flower; c. flower with 2 tepals removed; d. anther; e. staminode; f. pistil (Womersley and Vandenberg NGF 37195).

\section{RESULTS AND DISCUSSIONS}

Similar to Endiandra fulva vegetatively but E. kassamensis has more lateral veins and coarser reticulation. The flowers of Endiandra kassamensis bears no staminal glands but staminodes are present. - Type: Womersley and Vandenberg 37195 (holo BO; iso SING), Kassam Pass, Kainantu, Eastern Highlands District, PNG.

Tree up to $43 \mathrm{~m}$ high, $90 \mathrm{~cm}$ in diameter. Twigs solid, dark brown, glabrous. Terminal buds conical, big, with densely pubescent with short appressed hairs. Leaves alternate; petiole thin, canaliculate above, ca. $1 \mathrm{~cm}$ long, glabrous; blade coriaceous, narrowly elliptic to elliptic, 11-14 x 3-6 cm, glabrous on both surfaces, apex acuminate, base cuneate; midrib flat to slightly impressed above, raised below, both surfaces glabrous; lateral veins diverging, 10-11 pairs, slightly raised, glabrous on both surfaces; minor venation coarsely reticulate, prominent. Inflorescences paniculate, bear many flowers, up to $12 \mathrm{~cm}$ long, terminal or axillary, with sparse short hairs; bracts caducous; pedicels slender, ca. $3 \mathrm{~mm}$ long, with dense curly hairs. Flowers brown (fresh), erect, $2 \mathrm{~mm}$ in diameter; tepals thin, soft, subequal (inner ones smaller), narrowly ovate, outer ones 
1.2-1.5 x 1-1.2 mm, inner ones 1-1.2 x 0.8, with sparse long curly hairs outside, same inside especially basal part at anthers attachment; glands none; stamens 3; anthers somewhat triangular, 1 x $0.6 \mathrm{~mm}$, glabrous; filament short, $0.1 \mathrm{~mm}$ long; locules small, roundish; staminodia 3, pentagonal, $0.4 \times 0.3 \mathrm{~mm}$, with curly hairs; receptacles deep, with curly hairs; ovary ovoid, $0.6-0.9 \mathrm{~mm}$ long, glabrous; style ca. $0.3 \mathrm{~mm}$ long; stigma inconspicuous. Fruits unknown.

Distribution - Eastern Highlands District (PNG). Habitat \& Ecology - Rain forest, on hillside, subcanopy; alt. 1280-1372 m. Specimens examined (3 sheets) - Coode \& Dockrill 32655 (BO); Womersley \& Vandenberg 37195 (BO, SING).

Notes - Endiandra kassamensis Arifiani is different from other species of Endiandra in New Guinea because of the composition of its flowers. The species bears no glands but interestingly staminodia are present. Vegetatively, E. kassamensis is similar to E. fulva Teschner but bears more lateral veins and coarser reticulation. Endiandra kassamensis is endemic in New Guinea and has a restricted distribution, i.e. in the eastern part of New Guinea (Papua New Guinea) and was not found further West in West Papua. Futhermore the species grows only in a relatively high altitude forest. According to Rohwer (1993), the diversity of Lauraceae species are higher in lowland forests, which is in agreement with the diversity of Endiandra in general except for several species of Endiandra including E. kassamensis that was only found in higher altitude forests, in the restricted area of Kassam Pass, Kainantu Subdistrict. This fact leads E. Kassamensis to be considered a rare species. Detailed studies of endemic and rare species of Endiandra are important for providing information for decision makers in allocating conservation efforts.

\section{CONCLUSIONS}

Endiandra kassamensis is described for the first time in this study. It is a rare species and endemic to New Guinea.

\section{ACKNOWLEDGMENTS}

The first author graciously thanks Prof. Mien A. Rifai for valuable guidance and constructive suggestion during the research and to Dr. Sri S. Tjitrosoedirdjo for valuable discussion and support during the research and preparation of the manuscript. We acknowledge the generosity of the curator of SING herbarium for the loan materials. We would like to thank the anonymous reviewer for the important comments and to $\mathrm{Mr}$. Subari for the botanical line drawings. 
Endiandra kassamensis (Lauraceae) a new species from Papua New Guinea - Deby Arifiani et al.

\section{REFERENCES}

Arifiani D. 2012. The biosystematic study of Endiandra R.Br. (Lauraceae) in New Guinea [dissertation]. Depok, Indonesia: Universitas Indonesia. $144 \mathrm{p}$.

Brown R. 1810. Prodromus Florae Novae Hollandiae et Insulae Van Diemen. Typis Richardi Taylor et Socii, London.

Hyland BPM. 1989. A revision of Lauraceae (excluding Cassytha). Aust Syst Bot 2: 135-367.

Kostermans AJGH. 1957. Lauraceae. Reinwardtia 4: 193-256.

Rifai MA. 2011. Asas-asas Sistematika Biologi. Herbarium Bogoriense, Pusat Penelitian Biologi-LIPI, Bogor.

Rohwer JG. 1993. Lauraceae. In: Kubitzki K, Rohwer JG, Bittrich V. editors. The Families and Genera of Vascular Plants II. Berlin: Springer Verlag.

van der Werff H, Richter HG. 1996. Toward an improved classification of Lauraceae. Ann Mo Bot Gard 83: 40918.

Veldkamp JF. 1987. Sequence of organs and terminology of characters. In: Manual of Herbarium Taxonomy, Theory and Practice, de Vogel E.F, editor. UNESCO. 